\section{The Down-Deep Delight of Democracy}

\section{Reviewed by: Melis Oguz, Technische Universität Berlin, Germany}

In his book entitled The Down-Deep Delight of Democracy, Purcell is first looking at the discourses of pioneer thinkers, Aristotle, Plato, Hobbes, Lefebvre, Deleuze and Guattari, Ranciere, Laclau and Mouffe. While at the very beginning, as a reader, you might come up with the question, 'why do I need such a summary and what will this study be actually be about', Purcell answers soon enough in the third page, 'What we need in our time is to move politically from oligarchy to democracy, from positivity to activity and from heteronomy to autonomy'.

In this study, Purcell meticulously prepares a very 'elementary' conceptual basis for the reader and starts describing different ruling systems. Purcell argues the options available - state socialism, welfare state approach and neoliberalism, in their own way - are nothing other than a form of oligarchy. None of these options, according to Purcell, offers a properly 'democratic' response to Lenin's question, 'What is to be done?'

By referring to pioneer thinkers and their conceptualizations, Purcell is trying to familiarize to his idea, which he will just introduce to the reader as subliminal messages in the very first half of the book - which comes up to the surface only in the second half of the book as a crystal clear message. Purcell with this strategy actually succeeds something very significant: The moment he explains his 'answer' to Lenin's question, the reader is already having the same, or almost a similar, answer due to all the subconscious signs the reader was confronted until then.

The modern state is here to keep order in society and is nothing but a Leviathan, as Hobbes referred to. We live in a world that equates democracy with a liberal-democratic state, which is a form of oligarchy that sets severe limits on democracy and insists that anything beyond those limits is impossible; Purcell tries to make clear that how democracy is described and 'subliminally advertised' is totally against the idea of democracy.
For ancients such as Aristotle, the demos did not mean the people as a whole. Rather, it referred only to the many poor who were not members of the elite classes. Aristotle assumed that these poor were always the majority but they never constituted everyone in society. Thus, democracy, the rule of the demos, was for Aristotle the rule of the many poor over everyone else. The modern innovation, for Hardt and Negri, was to extend absolutely this concept of the demos from the many poor to everyone. As a result, modern democracy becomes the rule of everyone over everyone or absolute democracy.

In a democracy, everyone governs everyone. And so, Hardt and Negri argue, modern democracy cannot tolerate the gap between representatives and everyone. Representative democracy is therefore a contradiction. Representation and democracy contradict each other, yet they have become synonymous.

To strengthen his response to Lenin's question, Purcell makes use of Lefebvre's notions on the industrial city and urban society. The industrial city is a city in which private property and exchange value are the dominant ways to organize urban space. It is a city in which the dominant sociospatial processes separate and segregate people from one another, and those separated parts are homogenized and made equivalent so that they can be exchanged on the market. In the industrial city, urban inhabitants are rendered politically passive, and they function primarily as customers rather than as citizens. These inactive inhabitants are warehoused in sterilized urban spaces, 'habitats'. Today, we call this the neoliberal city. Lefebvre's contemporary, Guy Debord, called it 'the society of the spectacle'. There are differences in how each thinker conceives of what it means to become active, but there is a broad agreement that becoming active means necessarily becoming active as well. Laclau and Mouffe don't much explore the line between action and inaction, between those people that mobilize and those that do not.

Lefebvre posits urban society as a virtual object, as a horizon towards which we must move but that we can never reach. Lefebvre says, our struggle to forge urban society, or a new land, can very much be, and usually are, a struggle to revolutionize the 
space we are currently living in. So, urbanization itself is a revolution.

It is thus not coincidental that the latest revolutionary and much-ballyhooed resistances are mainly against the urban developments. In June 2013 in Turkey, an unexpected resistance came up. A small group of activists mainly consisting of university students, architects and city planners occupied Taksim Gezi Park, Istanbul, in order to stop demolishment of the park and trees. The sparkle was an opposition towards an urban development project, which meant to destroy a central park in Istanbul and rebuilt the area into a shopping and touristic complex. The police acted brutally towards the protestors who were few in numbers. The brutality of the police was the last drop to bring people to the end of their rope. Everyday more and more people joined the protestors in Gezi Park; the more people joined the resistance, the brutal was the police. Suddenly, it was not an opposition towards an urban development project anymore.

The symbols of the resistance have remained as the trees, which were torn down - yet they were metaphors for everything which was lost or feared to be lost during the ruling of the current government. Various people from various sections from the society, from different political orientations, from distinct ethnicities, from diverse religions, with varying sexual choices were resisting together their common point was that they were feeling all threatened by the undertaking of the government and they were feeling that the space they are 'allowed' to live is getting more and more squeezed.

This spirit of resistance spread to many cities in Turkey. Their desire to be active can become strong, as it did in so many places, but it can also become dormant again. Purcell (2013: 118) explains this with these words, 'Our inner desire to "let someone else do it" will always return to seduce us. How much easier it would be not to go to the meeting or the demonstration, not to become informed and think through an issue, not to suffer the angst of responsibility that comes with making a decision. Let the oligarchs decide.... Our desire to be ruled is strong, at least as strong as our desire to manage our own affairs. The act of becoming aware and becoming active is therefore only a first step'. Maybe what followed the protests can be an answer to Lefebvre; in his work, The Production of Space, he was concerned about 'the silence of the users of space. Why do they allow themselves to be manipulated in ways so damaging to their spaces and their daily life without embarking on massive revolts?'

It is important to understand that for Lefebvre these two concepts are of different kinds. The industrial city is what he calls 'actual': It is 'a clearly defined, definitive object' that has in fact been realized. It is realized both as a concrete, built form and as a set of normalized social relations, habits of action, thought and common sense. Urban society, on the other hand, has mostly not been realized. It is what he calls a 'virtual or possible object'.

Using Gramsci's concept of hegemony, an acceptance of categories of rulers and ruled, Purcell relates to representative democracy. The excuse for the need for representation is based on the statement that if everyone would come to the political community as equals, then there would be no natural order pre-existing such communities. 'The equality of anyone at all with anyone else' presupposes a form of an arkhe. Yet, as Ranchiere expresses, it is also democracy's basic assumption. In short, anarchy is inherent to democracy.

For Aristotle, the master is master because he has logos; the slave is a slave because he does not. But, Ranciere points out, even Aristotle sees the problem: The slave must understand a command when it is used. He must understand that he is obligated to obey that command. He therefore must be able to take part in an exchange using logos, which is to say he must already in some sense be equal-inlogos to the person who is giving the commands. It is in that primary contradiction of politics, that Ranciere sees irrefutable evidence of the contingent and constructed nature of all orders, of the Hobbesian base condition of human society, which is that everyone is equal to everyone else.

Society and equality work at opposite purposes. Joseph Jacotot argues that there is 'an inegaliterian logic inherent in the social bond'. It is impossible to achieve a society without inequality.

Heteronomy means to be ruled by another, whereas autonomy means to rule oneself. Oligarchy necessarily institutes a heteronomic relation, because 
the few (others) rule the rest. Democracy instead constitutes autonomy: Everyone rules himself/herself. Heteronomy is a condition in which the power of everyone to govern himself/herself has been alienated, expropriated by an organ, a few, an-other. Democracy insists that people never agreed to surrender their power in the first place. The state cannot live without our desire to be ruled.

To become democratic is to become adult; it is to rule oneself, to struggle every day to be autonomous. For Wallace, it is extremely hard to grow up because we are afraid to experience this anxiety, we want to remain infants, to be passive, to be taken care of. He even suggests that this desire for the crib is stronger than any other desire, even stronger than our desire to stay alive.

Ipso facto, the first step for democracy is awareness by understanding that the addiction - becoming-passive - is a problem. When people become active, they can radically increase their estimation of their own abilities. That people believe they are incapable of ruling themselves and that there would be chaos without any hierarchical authority is the general agreement that legitimate power rests on. To say we are too immature for democracy and therefore we must be ruled by an oligarchy - that would be to cure the disease with the germ that is making us sick.

Democracy and activity are, as Lefebvre says, a horizon. They are something we aim at and struggle towards, a destination we want desperately to reach, even though we know we never can. We can never be democratic, we can only ever be in progress of becoming democratic. Democracy can only ever be the struggle for democracy, the journey down a path towards more democracy, autonomy, and activity.

\section{Spatial Delight and the Possibilities of Childhood}

\section{Reviewed by: Simon Springer, University of Victoria, Canada}

When I was a child I used to play a game, spinning a globe or flicking through an atlas and jabbing down my finger without looking where. If it landed on land I'd try to imagine what was going on 'there' 'then'. How people lived, the landscape, the time of day it was, what season. My knowledge was extremely rudimentary but I was completely fascinated by the fact that all these things were going on now ... It's partly a way of imagining how things are for friends in other places; but it's also a continuing amazement at the contemporaneous heterogeneity of the planet.... And this is where space comes in ... it is quite reasonable to take some delight in the possibilities it opens up.

Doreen Massey (2005: 14)

No one has yet fully realized the wealth of sympathy, the kindness, and generosity hidden in the soul of a child. The effort of every true educator should be to unlock that treasure.

Emma Goldman (1931/2011: 409)
Let her go places that we've never been, trust and delight in her youth.

Neil Gaiman (2011: n.p.)

Mark Purcell's (2013) latest book, The Down-Deep Delight of Democracy is a tremendously important political intervention that comes at exactly the right moment. As humanity collectively chokes on the miasma of the neoliberal present, wherein capitalism has become explicitly punitive, the apparatus of the state has lost all false claims to benevolence, individualism has metastasized in the form of apathy and alienation, and the spirit of democracy has been incinerated in the inferno of an evertightening security regime of militarism and fear, Purcell boldly sounds a clarion call to resistance. The oligarchies of oppression that deprive our freedoms, sequester our desires, and divide our communities, while undoubtedly extremely powerful in the current conjuncture, are not without challenge. Reflecting on the importance of theorizing and practicing democracy in a radical sense of autonomy, Purcell links his understandings of collective empowerment to a more relational and processual conceptualization of space. Viewing democracy as a forever-unfolding stream of becoming, it is in this 